\title{
Floodplains and sustainable development
}

\author{
F. Rochford \\ La Trobe University, Australia
}

\begin{abstract}
Australian floodplains are environmentally significant, carrying high biodiversity loads. International conventions, state and federal laws protect them to an extent. However, since Australian flood events, when they occur, can affect massive areas of farmland, and cause significant damage to urban private property and state infrastructure, floodplain management is a balance of competing interests. The management of flooding events and conservation of water has resulted in a legacy of structures that capture, divert or restrain floodwaters, resulting in a range of environmentally damaging effects.

This paper considers the impact of infrastructure on recent flooding in northern Victoria, considering the degree to which flooding followed the natural flow of water, and what constrained its flow. It considers particularly the impact of regulations and planning decisions on floodplain management. It also considers the impact of the implementation of environmental watering requirements under the Water Act 2007 (Cth) and the potential impact of environmental watering on state liability for flood damage of private infrastructure.
\end{abstract}

Keywords: environment, law, planning, infrastructure.

\section{Introduction}

Extensive floodplains characterise the Australian geography, and the management of floodplains from ecological and planning perspectives attracts significant literature. Balancing the needs of an ecosystem reliant on intermittent but extensive flooding with private and public infrastructure is an acknowledged problem in Australian natural resource management. However, to date much literature has been devoted to the amelioration of the effects of natural flood events, and the management of liability risks arising from infrastructure 
planning. The risk generated by environmental watering by government authorities is an issue of relatively recent provenance.

This paper first considers the role of floodplains in Australia's ecosystems, noting broadly the consensus as to the need to provide Environmental Water Allocations to periodically water significant floodplains. It sets out the legislative framework within which Environmental Water Allocations are to be provided, concentrating in particular on the provisions of the Water Act 2007 (Cth), which imposes requirements on the states to create environmental flows.

The potential liability of state and federal agencies for non-natural flooding of public and private infrastructure must be considered in the context of the statutory machinery established to facilitate environmental flooding. This paper will consider the statutory framework and the common law rules to ascertain potential litigation risk, and concludes that far more needs to be done to detail the consequences of environmental flooding regimes.

\section{Litigation risk factors}

As recent flood events have indicated, much of inland Australia is subject of flooding. The massive extent of inland flooding, much like the recent catastrophic drought period, illustrates the limits on the human capacity to control, or even ameliorate, severe weather events in Australia. Within those limits, however, measures have been taken to live and work on Australian floodplains. Indeed, the fact that they are floodplains means that these are some of the more fertile areas of the Australian inland. The extent of flooding also cautions that it is a nonsense to suggest without caveat that there should be no development on floodplains.

Nevertheless, floodplain development must occur with reference to a number of factors: the risk of inundation and the consequent destruction of public and private infrastructure, the risk to life, both in the initial period of inundation and as a consequence of the increased risk of disease due to inundation, stock losses and business losses as a result of flooding, and the risks to natural floodplain ecosystems if inundation is modified or reduced. This can translate into potential litigation risk, particularly to public authorities, whose planning decisions and frameworks have enabled construction and whose response to risks can come under scrutiny.

There are second-level risks, too. If development occurs on floodplains the risks need to be managed, and the management of those risks tends to lead to unintended - if not unanticipated - consequences. The inundation of private assets, particularly in townships, requires massive investment in levees and drainage works and rescue and recovery operations, and the role of this infrastructure is necessarily going to push floodwater into areas into which it would not otherwise have gone. The construction of flood mitigation dams leads to the potential for catastrophic flood events if the dam fails or dam releases result in flooding, as occurred in the case of the Wivenhoe Dam in Brisbane.

The steering role of insurers to define, manage, spread and shift risks has been demonstrated in the aftermath of recent flood events, with some insurers 
relying on distinctions between riverine and non-riverine flooding to deny claims, and others applying significant premium increases to properties in regions considered to be subject to inundation. The expected response of insurers to the findings of the Commission of Enquiry into the operation of the Wivenhoe Dam is likely to be legal action against the dam authority, which shifts losses to the public through Queensland's arrangements for maintaining infrastructure.

Finally, and problematically, the recent policy imperative to create and design a satisfactory framework for environmental flows has created a new set of litigation risks. Holding environmental water increases the risk that a dam will spill or overtop its banks, and the release of an environmental flow increases the potential for inundation. In the current legislative framework, the risk sharing arrangements between the Federal and State governments and landholders are a significant planning feature.

\section{The significance of Australian floodplains}

The environmental significance of floodplains is long-established. Australian ecosystems have adapted to intermittent inundation to the extent that controlling inundation has the capacity to diminish ecosystem health. The importance of flooding events to the ecosystem is dependent, however, on the context. As Kingsford and Thomas note, '[l]arge floodplain rivers are dynamic ecosystems with enormous spatial and temporal complexity. Flood channels, backswamps, braids, marshes, distributories, billabongs and wetplains make up the floodplain of a large lowland river' [1]. Interference with this pattern of inundation on a basin scale has occurred through the regulation of rivers to reduce flood events and to conserve water for irrigation and stock and domestic use, the extraction of water, mainly for irrigated agriculture, more effective drainage, reducing the length of inundation periods and increasing inflows into rivers, and infrastructure on floodplains, including roads and railways, irrigation channels, drains, private and public levee banks, and irrigation check-banks.

It should be noted that the comparative importance of the ecosystem and anthropogenic values of floodplains is an essentially political decision; as recent flood events demonstrate, humans could not sustain a settled population in inland Australia without managing the catastrophic effects of flooding; any more than they could survive without ameliorating the effects of drought. Whilst drought and flooding are necessary components of Australian ecosystems as they have evolved, the necessary consequence of having a non-nomadic and growing human population in Australia is some regulation of extreme weather events. The comparative importance of ecosystem values and human production assets has shifted over time, as has the attitude to shifting and sharing the risk of loss.

Accordingly, when the ecosystem values of Australian floodplains are discussed, they should be assessed not on a general basis, but on a system of optimal ecosystem preservation values. However, because floodplain connectivity is also an issue, ecosystem preservation is both a local and an integrated issue. The 'maintenance of natural patterns of longitudinal and lateral 
connectivity is essential to the viability of many riverine species' [2]. However, in arid regions, low-relief topography, increased evapotranspiration and variability in rainfall and runoff, and the El Nino/Southern Oscillation effects 'combine with the complex riverine landscape to produce highly variable levels of connectivity' [2].

Australia's obligations to protect floodplain ecosystems commence with International Instruments to which Australia is a party. Australia is signatory to the Ramsar Convention on Wetlands of International Importance (the Ramsar Convention), the Convention on Biological Diversity, the Convention on the Conservation of Migratory Species of Wild Animals (the Bonn Convention), the Convention Concerning the Protection of the World Cultural and Natural Heritage (the World Heritage Convention), the World Charter for Nature, and Agenda 21. Whilst legislative authority to manage most environmental matters resides with the states, the Federal government attracts legislative competence through the external affairs power in s.51(xxix) of the Constitution, and has exercised this power through the Environment Protection and Biodiversity Conservation Act 1999 (Cth). The Water Act 2007 (Cth) is also based in part on the external affairs power, and the objects of that Act specify in particular that the Act is to '(b) give effect to relevant international agreements..., and (c) in giving effect to those agreements, to promote the use and management of the Basin water resources in a way that optimises economic, social and environmental outcomes.'

Leading commentators have argued, therefore, that consistency with international conventions will be required to ensure legislative competence [3]. Thus, priority must be given to environmental sustainability in implementing the provisions of the Act and the making of the Murray-Darling Basin Plan. Section 21(1) of the Water Act 2007 (Cth) makes this clear:

The Basin Plan ... must be prepared so as to provide for giving effect to relevant international agreements (to the extent to which those agreements are relevant to the use and management of the Basin water resources).

Assessing the relevance of floodplains to Australia's responsibilities as signatories to these Conventions is critically important. But this gives rise to massive difficulties of definition and scale. As Australian floodplains extend over almost half of the continent, but the recharge of wetlands depends on their continued interconnectivity, political questions arise as to the protection of infrastructure and public and private investment consistent with the preservation of wetlands. The precautionary principle has been explicitly included in the political agreements that inform the legislative program [4] and in Australian common law [5], and this demands that 'a lack of scientific certainty should not prevent the implementation of measures needed to prevent irreversible or serious environmental damage' [4], but a high degree of variability is something to which the ecosystem has evolved, and is something which should be replicated in attempting to remediate the effects of floodplain development. 
Accordingly, environmental water holders in both state and federal jurisdictions attempt to ameliorate the effects of altered water flow regimes by targeted environmental watering. This requires a complex reallocation of rights and duties between the states, with the primary responsibility for the administration of water, and the Commonwealth bodies empowered by the federal Act to effect environmental watering. The Commonwealth Environmental Water Holder manages the Commonwealth's water holdings pursuant to s.105(1) of the Water Act 2007(Cth) and has a duty to manage water holdings in accordance with the environmental water plan - which is part of the Murray-Darling Basin Plan still in preparation - other relevant plans, operating rules and environmental water schedules (s.105(4)). Section 106 prevents the disposition of water other than in accordance with those instruments unless the water is not necessary to meet the objectives of an environmental water plan.

Clearly, however, this requires consequential reallocation of risks, since the infrastructure required to store and deliver environmental water holdings is administered by the states, and the infrastructure risks as a result of running the reservoir at a greater capacity, or instituting a spill, or piggy-backing on a highflow, are in the hands of the states.

This is not merely theoretical. Disputes have already arisen between the Snowy Hydro, the administrator of the Snowy Mountains Hydroelectric Scheme and the dams in the Snowy Mountains, and the New South Wales Water Commissioner.

Snowy Hydro proposed an environmental release of to relieve 'uncomfortably high dam levels,' but the NSW Water Commissioner initially refused 'because of a technical accounting dispute over who would notionally pay for the water, and to conserve water in case global warming comes good' [6]. The 'airspace' issue, which relates to the amount of free space in the dam to mitigate the possibility of overtopping or dam failure, was also an issue in the management of the Wivenhoe Dam in Queensland. The dam was originally built as a flood mitigation measure, and water storage capacity was to be augmented by the planned construction of new facility. This facility was never built, and at the time of the Brisbane flooding in January 2011 the dam was the primary water supply facility for Brisbane, and after a major drought it has been theorised that flood mitigation was not then a priority. As a result of massive inflows during January 2011 the dam was at risk of overtopping and failing. A Commission of Inquiry has recently been concluded, finding that SEQ Water, the instrumentality charged with administering the dam, did not comply with its operating manual. The outgoing Queensland Premier, Anna Bligh, conceded that legal action against the state was likely [7].

\section{Common law background}

The common law rules apportioning liability for damage as a result of flood events are of long standing, but are not always clear. Liability is primarily assessed through the common law of nuisance and negligence. The common law 
distinguished between floodwater and the drainage of surface water, although this distinction is difficult to draw.

Common law authorities were unclear as to whether landowners were able to use any measures necessary to protect their land, or whether landowners were permitted to take such measures as were reasonably necessary as long as they used reasonable care and skill. The rules were set out in Gartner v Kidman (1962) 108 CLR 12, however much of those rules could be set to be obiter, because the case itself only required resolution of a dispute in which a lower landowner was entitled to obstruct the flow of surface water in a depression [8]. The facts of that case are typical of supply issues - where the parties are concerned about rights to the flow of water. The same law could apply, however, where the nuisance or negligence arises from the excessive flow of water; whether because of obstructions placed into the path of water which diverts water onto previously unaffected land, or the construction of works which move water more quickly onto affected land. Nuisance and negligence principles may also apply where water which has been tainted by chemicals, hormones, genetically modified organisms or other substances and affects crops or animals on land.

Nuisance has historically applied to emanations from land. It is the unreasonable interference with another person's use and enjoyment of land. This is a question of degree, and takes into account considerations such as the nature of the interference, its intensity and duration or frequency, and its cause.

In Munro v Southern Dairies Ltd [1955] VLR 332 the court noted that private nuisance is

\begin{abstract}
'An unlawful interference with a person's use or enjoyment of land, or of some right over, or in connection with it,' but that definition of itself is so wide that it is necessary to add to it and qualify it in order to set out clearly what it is that will constitute an actionable private nuisance of the kind here complained of. In the first place, there must be a substantial degree of interference with the comfort and convenience of the occupier who complains of a private nuisance, or with some other aspect of the use or enjoyment of his land. The interference must be so substantial as to cause damage to him.
\end{abstract}

This can be applicable to water escaping from land in a number of contexts, particularly due to obstructed drains, as in Sedleigh-Denfield v O'Callaghan (1940) AC 880, or damaged pipes, as in Montana Hotels Pty Ltd v Fasson Pty Ltd (1987) Aust Torts Reports $₫ 80-109$. Nuisance has traditionally also applied to pollution of groundwater.

In some jurisdictions nuisance was applied to artificial erections which cause floodwaters to flow onto neighbouring land: Broder v Saillard (1878) $2 \mathrm{ChD}$ 692; Hurdman v North Eastern Railway Co (1878) 3 CPD 168. This would be a significant principle to apply to the widespread channel, rail and road infrastructure that blocks or impedes the flow of floodwaters across the enormous Australian floodplains. Of course, it would also apply to levy banks 
deliberately erected to protect towns and infrastructure from floodwaters. Floodplain development can cause ecosystem problems by severing wetlands from rivers and preventing the flooding of floodplains [9]. It can also cause damage to land caused by flooding where that land would not naturally flood. The reform of planning provisions to allow development of land with recognised 'flood overlays' both alters the flow of water and increases the potential for private and public infrastructure loss. However, Australian authorities applied that English rule relating to obstruction of flows only where the artificial erection was not a natural or reasonable use of land: Kraemers $v$ AG [1966] Tas SR 113; Furness v Clarke (1970) 1 SASR 359 (Chamberlain J).

In the context of the escape of large quantities of water, as in for instance, the case of a dam breach, the principles were derived from Rylands $v$ Fletcher (1868) LR 3 HL 330. That case applied the statement of Blackburn $\mathrm{J}$ in Fletcher $v$ Rylands (1866) LR 1 Ex 265 to the effect that:

the person who for his own purposes brings on his lands and collects and keeps there anything likely to do mischief if it escapes, must keep it in at his peril, and, if he does not do so, is prima facie answerable for all the damage which is the natural consequence of its escape. He can excuse himself by shewing that the escape was owing to the plaintiff's default; or perhaps that the escape was the consequence of vis major, or the act of God; but as nothing of this sort exists here, it is unnecessary to inquire what excuse would be sufficient.

In application to the escape of water, a large accumulated mass of water stored in a reservoir satisfied the 'mischief' or 'danger' test for the purposes of the rule.

However, that case has more recently been subsumed into the general Australian law of negligence by Burnie Port Authority v General Jones Pty Ltd (1994) 179 CLR 520. In application to water stored on land, therefore, if a person uses their land to carry on a dangerous activity, or to allow another so to do, they may be liable under a normal rules of negligence but with a heightened standard of care, amounting in relevant cases to a non-delegable duty - a duty which is not discharged by the appointment of reasonable contractors.

Of course, however, the statutory context in which the reservoir was operated is relevant to liability if the dam is operated by the State: Crimmins $v$ Stevedoring Industry Finance Committee (1999) ALR 1. In Graham Barclay Oysters Pty Ltd v Ryan (2002) 211 CLR 540 the court said:

An evaluation of whether a relationship between a statutory authority and a class of persons imports a common law duty of care is necessarily a multi-faceted inquiry. Each of the salient features of the relationship must be considered. The focus of analysis is the relevant legislation and the positions occupied by the parties... 
Whereas State authorities are unlikely to be made liable for matters of policy, they may be liable for implementation of policy. It is clear that, for instance, that 'the purposes or functions peculiar to government' will not give rise to liability: Maguire v Simpson (1977) 139 CLR 362, 393-395 (Stephen J), 408 (Murphy J); Commonwealth v Evans Deakin Industries Ltd (1986) 161 CLR 254. Courts perceive themselves to be incompetent to review decisions based on value judgments, policy judgment and decision, particularly since

almost all acts of government hurt someone, and it would be utterly impracticable to assess and order compensation for every injury inflicted by government. Even if one were to limit such compensation to injuries caused by government fault, the impracticability of complete compensation remains. ... [C]omplete liability would inhibit governments from acting. ... [A] complete fault-liability scheme would be an enormous force for conservatism [10].

State legislation demonstrates the manner in which liability can be managed.

\section{Legislative framework}

Where state authorities artificially create flooding to provide ecosystem benefits, or maintain dams at an artificially high level to retain water for environmental flows and the dam is subsequently forced to spill, inundating private land, state liability may be determined by reference to the common law of nuisance and negligence. However, the common law principles are to be determined by reference first to the legislative framework. In the Australian federal context, competence for water management is largely a state matter.

State-based organisations can be classified according to their role in policy development, resource allocation, administration, distribution, and monitoring and enforcement. Some of the bodies have exclusively judicial or quasi-judicial functions, while others operate on a policy or allocation principle level, and are thus unlikely to be affected by potential litigation in tort [11].

Thus, in Victoria, Division 2 of the Water Act 1989 (Vic) circumscribes the extent of state liability in some circumstances. Section 16 makes it clear that liability can arise from the unreasonable flow of water from land onto another's land, but s.17 specifies that no civil liability for an unreasonable flow of water arises except under the Act. Section 20 sets out the matters relevant to the question of whether a flow of water is unreasonable, and s.21 sets out the matters relevant to the question of liability for management of public works.

However, the federalisation of Australian water policy pursuant to the Water Act 2007 (Cth), although still leaving implementation matters in the hands of the States in deference to federal Constitutional restrictions, introduces major shifts in potential state liability. It requires states to implement the environmental flow 
requirements settled by the Murray Darling Basin Plan under the authority of the Water Act 2007 (Cth). The Plan, when it is finalised, will require environmental flows through an environmental watering plan. Section 28(2) of the Water Act 2007 (Cth) requires the specification of objectives and targets and the identification, prioritisation and management framework by which the environmental outcomes are to be achieved.

The mechanisms by which 'environmental watering' is to be achieved are still inchoate and are currently run in conjunction with state environmental watering plans. Environmental water holders at state and federal level obtain and store water in reservoirs and release that water for targeted environmental purposes, typically 'piggy-backing' on natural flood events or irrigation flows. The extent of the targeted flooding events is not clear, but if attempts are made to reinstate natural flooding regimes on floodplains the damage to private and public infrastructure will be marked. Politically it is likely that flood events will initially be restricted to targeted wetlands still attached to river systems, such as the Barmah Forest or Coorong Lake systems, which have the benefit of also being state-owned.

As more ambitious flooding regimes are proposed, risk assignment under the legislation is significant. The National Water Initiative focused on the allocation of risks due to water allocation changes, assigning risk according to whether it was due to drought, climate variation, bona fide changes in knowledge, or government reallocation. The Water Act 2007 (Cth) incorporates risk assignment mechanisms in Part 2, Division 4.

Significantly, however, the National Water Commission has concluded that there is uncertainty in the interpretation and implementation of the risk assignment terms in the National Water Initiative [12]. Whereas the risk factors specifically identified in the Act and in the National Water Initiative have tended to be in relation to the reduction in water entitlement, and risks have been apportioned between water access entitlement holders, relevant state governments and the federal government, the risks due to massive flood events do not appear to have been considered in great detail.

\section{Conclusion}

Justice Holmes, who conducted the Commission of Inquiry into the Wivenhoe Dam, noted in the preface to the report:

Years of drought did not promote rigour in flood planning, whether in relation to disaster response, dam management, or land use... Complacency about flood prevailed, at least in parts of the state, over many years. And there is a risk that the recommendations made here will be enthusiastically taken up in the short term, but, absent another flood disaster in the next few years, priorities will drift and the lessons will be forgotten [7]. 
A similar set of priority shifts arise in relation to management of environmental water in a long wet period after a significant dry period. Whereas the law has been enacted and the policies formulated, the massive problems of implementation appear to have been taken as capable of solution.

\section{References}

[1] Kingsford, R.T., Thomas, R.F., 'Use of satellite image analysis to track wetland loss on the Murrumbidgee River floodplain in arid Australia, 19751998' (2002) 45 Water Science and Technology 45-53, p.45.

[2] Catherine Leigh and Fran Sheldon, 'Hydrological changes and ecological impacts associated with water resource development in large floodplain rivers in the Australian tropics' (2008) 24 River Research and Applications 1251-1270, p.1252.

[3] Paul Kildea and George Williams, 'The Water Act and the Murray-Darling Basin Plan' (2011) 22 PLR 9.

[4] Intergovernmental Agreement on the Environment May 1992.

[5] Rowe v Lindner (No 2) [2007] SASC 189.

[6] Ean Higgins, 'Nature swamps Snowy's 'drop in a bucket' flow' The Australian, March 14, 2012.

[7] Sean Parnell, 'Anna Bligh says legal action likely over floods in the way of inquiry findings' The Australian March 19, 2012.

[8] John Adams, Drainage of Surface Waters: Common Law Rights and Victorian Legislation [unpublished Master's thesis] 1976, p.93.

[9] CMM Steinfeld and RT Kingsford, Floodplain Development and Vegetation Health on the Macquarie River Floodplain of the MurrayDarling Basin (Wetlands and Rivers, School of Biological, Earth and Environmental Sciences, University of New South Wales, 2008), p.3.

[10] M Aronson and H Whitmore, Public Torts and Contracts (1982), p.59.

[11] Francine Rochford, 'Liability in negligence of water authorities for contaminated water' (2005) 10 The Australasian Journal of Natural Resources Law and Policy 39-80.

[12] National Water Commission, Australian Water Reform 2009: Second Biennial Assessment of Progress in Implementation of the National Water Initiative (National Water Commission, Canberra, September 2009), p.193. 